\title{
Analyzing the effectiveness of Water Conservation Fee amidst growing water scarcity in India
}

\author{
Zainab Khorakiwala
}

\begin{abstract}
Water scarcity has become a significant issue in India, causing the central government to take various measures in addressing the issue through conservation efforts. This includes revising existing and formulating new regulation guidelines, creating awareness about conservation methods, and identifying critical and over-critical areas. In 2018, the concerned ministry endorsed the suggestion to levy Water Conservation Fee (WCF) on industrial, commercial, domestic and agricultural users of water in a bid to conserve depleting groundwater resources. The following paper aims to analyze the effectiveness of WCF, highlighting two major impediments to its success.
\end{abstract}

\section{INTRODUCTION}

Water scarcity, a global phenomenon, is now increasingly being recognized as a national issue due to the alarming data highlighting the existing water crisis in India. According to Niti Aayog's Composite Water Report (2018), around 600 million Indians are facing water stress, leading to approximately 2, 00, 000 deaths every year owing to inadequate access to safe water. This crisis is further likely to worsen as the demand is projected to be twice the supply of water by 2030. Furthermore, the report highlights that although in 2050 (a period of high water use) the demand for water is predicted to be milder [1,180 Billion Cubic Meters (BCM)], the current availability of water is $695 \mathrm{BCM}$. Thus, the forecasted low water demand is still higher than the possible available supply of water, which is projected at 1,137 BCM.

In India, water scarcity is mainly caused by depleting groundwater resources which serve as the dominant source of water for a majority of the sectors (domestic, industrial, commercial, and agriculture). Today, 54 percent of the groundwater wells are on a decline and as many as 21 states would have depleted their groundwater resources by 2020, thereby affecting a population of around 100 million. The depletion of groundwater mainly arises from its largescale consumption in the agricultural sector followed by the domestic and commercial (packaged drinking water) sectors. According to a report by the Standing Committee on Water Resources (2018), packaged drinking water accounts for 40 percent of water supply and has a share of 85 percent in the distribution of drinking water in rural areas. However, this commercial exploitation of groundwater has posed significant threats such as long-term decline of water resources and deterioration of water quality among others.

In order to tackle the issue of depleting groundwater resources, the Central Ground Water Authority (CGWA) released a new set of draft guidelines for the regulation and prevention of exploitation of groundwater resources in 2018. The draft consists of various measures such as rain water harvesting, guidelines regarding conservation of water, and need for a No Objection Certificate (NOC) for groundwater use (Ministry of Water Resources, River Development \& Ganga Rejuvenation, 2018). However, the most striking measure is the introduction of the Water Conservation Fee (WCF). The Ministry of Environment, Forest and Climate Change endorsed the suggestion to levy WCF on industrial units, infrastructure projects (including residential complexes) and the agricultural sector. Amidst growing water scarcity, the fee is 
expected to serve as a viable alternative to curb the exploitation of and ever increasing demand for water. However, the success of the measure depends on various factors. The following paper analyzes the effectiveness of WCF as a suitable economic instrument and mitigation strategy.

\section{BRIEF ANALYSIS OF WCF}

The proposed structure of WCF (as per the draft guidelines) requires industries and infrastructure projects to obtain an NOC in order to extract groundwater (Ministry of Water Resources, River Development \& Ganga Rejuvenation, 2018). All NOC groundwater users would be covered under WCF and taxed based on user-categories (domestic, commercial, agricultural, etc.) they belong to. For instance, users drawing water for drinking and domestic use would be taxed at a rate of Rs 1 per $\mathrm{m}^{3}$ and Rs 5 per $\mathrm{m}^{3}$ for water consumption between 25-50 $\mathrm{m}^{3}$ and greater than $50 \mathrm{~m}^{3}$ per month respectively. Mining industries and packaged drinking water units would be charged based on the amount of water extracted in a day and the condition of the area of extraction. Depending on the area (safe, semi-critical, critical and over-exploited), mining industries would be charged between Rs 1 (for extraction greater than $200 \mathrm{~m}^{3}$ per day) and Rs 7 (for extraction greater than $5000 \mathrm{~m}^{3}$ per day). Additionally packaged drinking water units drawing more than $50 \mathrm{~m}^{3}$ per day would be charged between Rs 3 and Rs 100, while those drawing less than $50 \mathrm{~m}^{3}$ per day would be charged between Rs 1 and Rs 20 .

Although WCF is a much required alternative, low rates and failure to reduce water consumption may not result in the expected outcomes. In the absence of an effective water pricing system that places a limit on water consumption, conservation efforts may prove to be challenging. The paper has identified regressive rates and a poor water pricing system as two major impediments to the success of WCF.

\section{Regressive Rates}

According to the proposed fee structure, WCF is not applicable to households drawing water through non-energized means or a delivery pipe measuring up to one meter in diameter (Ministry of Water Resources, River Development \& Ganga Rejuvenation, 2018). This provision is likely to incentivize a handful of users to rely on traditional methods of drawing water using a bucket, rope or hand pump, which are effective methods of water conservation. In contrast, a majority of the domestic and industrial users would have to pay WCF as they mainly draw water through mechanized extraction. In doing so, the fee also aims to prevent the settlement of new industrial units in critical and overcritical areas by charging higher rates of water extraction.

Although the WCF is seen as an effective economic instrument, it is important to note that the rates charged per cubic meter are abysmally low, which could translate into a situation where users would simply pay more to extract more. Moreover, in the absence of a provision placing an upper limit on the extraction of quantum of water, over-critical areas may be prone to greater risk. As a consequence, industrial units are likely to cause a faster depletion of the declining groundwater resources by agreeing to pay a minimal tax amount. In such a situation, the WCF may further desensitize people about the severity of the water crisis, thereby discouraging conservation practices.

\section{Poor Water Pricing System}

Being a scarce resource, water is both an economic and social good. It is, therefore, imperative that water is priced to ensure its efficient allocation among various competing sectors. Moreover, as a social good, it is equally important that the allocation of water meets the societal goals of social equity, poverty alleviation, and a healthy environment. Therefore, 
modern demand strategy accounts for both demand and supply, and recognizes charging water based on its marginal cost as one of the most productive ways of pricing. As a system, water pricing does not only entail charging consumption, but also recovering costs of inputs and capital goods invested in supplying water. In the absence of such a system, WCF is unlikely to be a suitable alternative.

The system of water pricing is certainly not alien to India, but it has largely been unproductive. According to a survey conducted across four Indian cities (Agra, Prayagraj, Pune and Bangalore), lack of data on water demand and its sensitivity to price fluctuations have been the major reasons for poor water demand management (Madhale and Kumthekar, 2015). Moreover, installed capacity is seen as coterminous with the water released, implying a supply of the entire amount of water stored irrespective of the demand. Furthermore, the survey shows that that there is no proportionality between water released and the price charged. The amount charged is much lower than the quantum of water supplied and it has been noted that most cities supply water free of cost to the users. For instance, free water released from public stand posts accounts stands at 15 per cent and 28 per cent in Agra and Prayagraj respectively. This has affected the financial viability of the water supplying agencies that find it increasingly difficult to recover costs, especially owing to the rising cost of electricity.

Finally, dysfunctional metered connections that charge the consumption of water further impairs the pricing system. In Agra, out of over 1, 00,000 metered connections, 80 percent have been reported as dysfunctional. Similarly, out of over 43,000 metered connections, 90 percent are dysfunctional in Prayagraj (Madhale and Kumthekar, 2015). This points towards the inefficiencies of the concerned government agencies entrusted with the responsibility to enforce appropriate controls on water consumption levels. In the presence of a crippled water pricing system, WCF would remain an effective alternative only on paper.

\section{CONCLUSION}

The goal of WCF as an economic instrument and policy alternative is to encourage people to bring about a change in their attitude towards the usage of water. However, this is unlikely to happen without any means to determine consumption patterns. Therefore, it is imperative that distribution of water is driven by the economics of demand and supply along with a robust taxation system (such as WCF) that pushes people towards conserving water.

\section{References}

Madhale, P. D., \& Kumthekar, D. (2015). Water Pricing Experiences in India: An Insight. International Journal of Applied Research, 1(10). Retrieved from http://www.allresearchjournal.com/archives/2015/vol1issue10/PartK/1-10-116.pdf

Ministry of Water Resources, River Development \& Ganga Rejuvenation. (2018). Guidelines to regulate and control Ground Water Extraction in India. Retrieved from Ministry of Water Resources, River Development \& Ganga Rejuvenation website: http://cgwb.gov.in/documents/New\%20CGWA\%20Guidelines\%20Gezette\%20Notification.pdf

Niti Aayog. (2018). Composite Water Management Index. Retrieved from Niti Aayog website: https://niti.gov.in/writereaddata/files/document_publication/2018-05-18-Water-Index-Report vS8compressed.pdf

Standing Committee on Water Resources. (2018). Socio-economic impact of commercial exploitation of water by industries. Retrieved from Ministry of Water Resources, River Development \& Ganga Rejuvenation website: http://164.100.47.193/lsscommittee/Water\%20Resources/16 Water Resources 23.pdf 